\title{
Reactive nitrogen partitioning and its relationship to winter ozone events in Utah
}

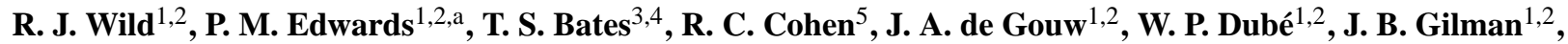 \\ J. Holloway ${ }^{1,2}$, J. Kercher ${ }^{6}$, A. R. Koss ${ }^{1,2}$, L. Lee ${ }^{5}$, B. M. Lerner ${ }^{1,2}$, R. McLaren ${ }^{7}$, P. K. Quinn ${ }^{3}$, J. M. Roberts ${ }^{2}$,

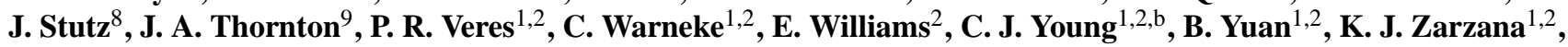 \\ and S. S. Brown ${ }^{2,10}$ \\ ${ }^{1}$ Cooperative Institute for Research in the Environmental Sciences, University of Colorado, Boulder, Colorado 80309, USA \\ ${ }^{2}$ Chemical Sciences Division, Earth System Research Laboratory, National Oceanic and Atmospheric Administration, \\ Boulder, Colorado 80305, USA \\ ${ }^{3}$ Pacific Marine Environmental Laboratory, National Oceanic and Atmospheric Administration, Seattle, \\ Washington 98115, USA \\ ${ }^{4}$ Joint Institute for the Study of the Atmosphere and Oceans, University of Washington, Seattle, Washington 98195, USA \\ ${ }^{5}$ Department of Chemistry, University of California, Berkeley, California 94720, USA \\ ${ }^{6}$ Department of Chemistry, Hiram College, Hiram, Ohio 44234, USA \\ ${ }^{7}$ Centre for Atmospheric Chemistry and Chemistry Department, York University, Toronto, Ontario, M3J 1P3, Canada \\ ${ }^{8}$ Department of Atmospheric and Oceanic Sciences, University of California, Los Angeles, California 90095, USA \\ ${ }^{9}$ Department of Atmospheric Sciences, University of Washington, Seattle, Washington 98195, USA \\ ${ }^{10}$ Department of Chemistry and Biochemistry, University of Colorado, Boulder, CO 80309 USA \\ ${ }^{a}$ now at: Department of Chemistry, University of York, York, YO10 5DD, UK \\ ${ }^{b}$ now at: Department of Chemistry, Memorial University of Newfoundland, St. John's, Newfoundland, A1B 3X7, Canada
}

Correspondence to: S. S. Brown (steven.s.brown@noaa.gov)

Received: 14 July 2015 - Published in Atmos. Chem. Phys. Discuss.: 7 August 2015

Revised: 23 October 2015 - Accepted: 8 December 2015 - Published: 19 January 2016

\begin{abstract}
High wintertime ozone levels have been observed in the Uintah Basin, Utah, a sparsely populated rural region with intensive oil and gas operations. The reactive nitrogen budget plays an important role in tropospheric ozone formation. Measurements were taken during three field campaigns in the winters of 2012, 2013 and 2014, which experienced varying climatic conditions. Average concentrations of ozone and total reactive nitrogen were observed to be 2.5 times higher in 2013 than 2012, with 2014 an intermediate year in most respects. However, photochemically active $\mathrm{NO}_{x}$ $\left(\mathrm{NO}+\mathrm{NO}_{2}\right)$ remained remarkably similar all three years. $\mathrm{Ni}-$ tric acid comprised roughly half of $\mathrm{NO}_{z}\left(\equiv \mathrm{NO}_{y}-\mathrm{NO}_{x}\right)$ in 2013, with nighttime nitric acid formation through heterogeneous uptake of $\mathrm{N}_{2} \mathrm{O}_{5}$ contributing approximately 6 times more than daytime formation. In 2012, $\mathrm{N}_{2} \mathrm{O}_{5}$ and $\mathrm{ClNO}_{2}$ were larger components of $\mathrm{NO}_{z}$ relative to $\mathrm{HNO}_{3}$. The nighttime $\mathrm{N}_{2} \mathrm{O}_{5}$ lifetime between the high-ozone year 2013 and
\end{abstract}

the low-ozone year 2012 is lower by a factor of 2.6, and much of this is due to higher aerosol surface area in the high-ozone year of 2013. A box-model simulation supports the importance of nighttime chemistry on the reactive nitrogen budget, showing a large sensitivity of $\mathrm{NO}_{x}$ and ozone concentrations to nighttime processes.

\section{Introduction}

Wintertime ozone air pollution has recently been observed in several North American basins and currently represents one of the most severe air pollution problems in the United States (Schnell et al., 2009; Carter and Seinfeld, 2012; Helmig et al., 2014; Rappenglück et al., 2014; Oltmans et al., 2014; Edwards et al., 2014). It has been associated with emissions from oil and gas operations coupled with meteorological con- 


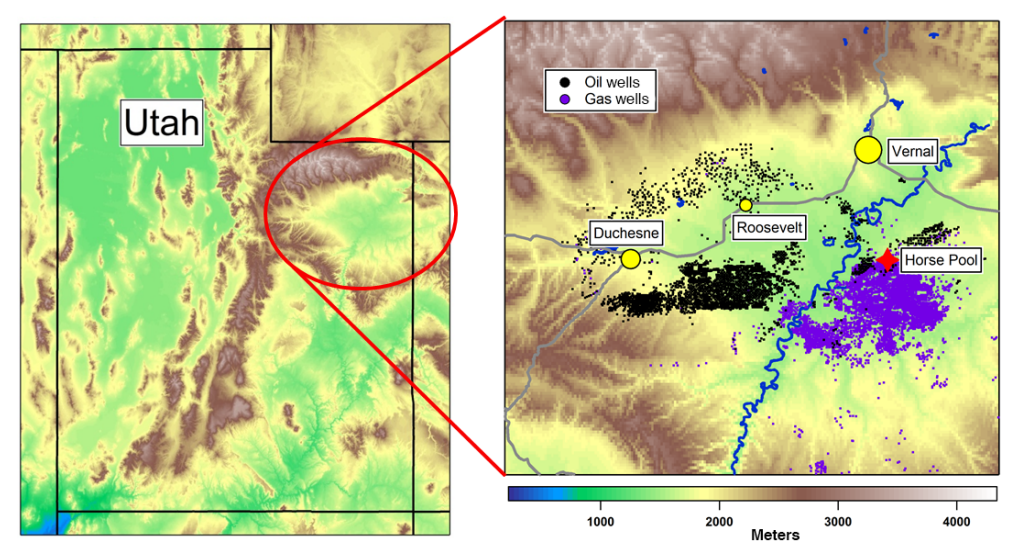

Figure 1. Map of the Uintah Basin in Utah, showing the Horsepool measurement site, active oil and gas wells, and the major population centers. The background is colored by elevation as shown by the color bar.

ditions that produce high surface albedo and temperature inversions, causing stable stagnation events. As with more conventional summertime urban air pollution, winter ozone production requires photochemistry of $\mathrm{NO}_{x}\left(=\mathrm{NO}+\mathrm{NO}_{2}\right)$ and volatile organic compounds (VOCs). In polluted areas, such as the Uintah Basin, $\mathrm{NO}_{x}$ is emitted mainly from fossil fuel combustion and can further oxidize to form reactive nitrogen species such as $\mathrm{HNO}_{3}$, acyl peroxynitrates (PAN), $\mathrm{N}_{2} \mathrm{O}_{5}$, $\mathrm{NO}_{3}, \mathrm{ClNO}_{2}$ and organic nitrates, which together with $\mathrm{NO}_{x}$ make up total reactive nitrogen $\left(\mathrm{NO}_{y}\right)$. Oxidation of $\mathrm{NO}_{x}$ occurs through different reaction pathways during the day than at night, but both contribute significantly to $\mathrm{NO}_{y}$ speciation. Some of these species tend to be permanent sinks of $\mathrm{NO}_{x}$, such as $\mathrm{HNO}_{3}$, whereas others such as PAN or $\mathrm{N}_{2} \mathrm{O}_{5}$ can act as temporary sinks (reservoirs) and revert to $\mathrm{NO}_{x}$ via photoor thermochemistry. Thus, an understanding of the reactive nitrogen budget contributes to understanding ozone formation.

To study the conditions and precursors that cause these anomalous wintertime ozone events, we deployed a suite of ground-based chemical, radiation, and meteorological measurements as part of the Uintah Basin Winter Ozone Studies (UBWOS) in 2012, 2013, and 2014. The UBWOS studies in 2012 and 2013 experienced very different meteorological conditions and yielded strikingly different results. In 2012, the lack of snow cover and the associated shallow inversions produced ozone with average values that showed distinct photochemistry but did not approach the $75 \mathrm{ppbv} 8 \mathrm{~h} \mathrm{Na}-$ tional Ambient Air Quality Standard (NAAQS), presenting a valuable baseline of chemical concentrations for this oiland gas-producing region (Edwards et al., 2013). In 2013, however, the snow cover resulted in strong temperature inversions, increased precursor concentrations, and increased photochemistry, which brought about elevated ozone levels (Edwards et al., 2014). The Horsepool measurement site in the basin experienced exceedances of the ozone NAAQS on 20 out of the 28 days of measurement in 2013. In 2014 the con- ditions were intermediate both meteorologically and chemically. A direct comparison of 2012 with 2013 provides valuable insight into the key elements that cause high wintertime ozone. In this paper we focus on reactive nitrogen and its partitioning during the two years to help explain the chemical processes that cause high ozone.

\section{Field campaigns and measurement techniques}

The three successive campaigns were conducted on 15 January-27 February 2012, 23 January-21 February 2013, and 28 January-14 February 2014 at the Horsepool site near Vernal, Utah. The site is located at $40.14370^{\circ} \mathrm{N}$, $109.46718^{\circ} \mathrm{W}, 35 \mathrm{~km}$ south of Vernal, Utah, the largest city in the basin. The basin is mostly rural, with a total population of 50000 concentrated mainly in three towns (Vernal, Roosevelt, and Duchesne). Approximately 10000 producing oil/gas wells are spread throughout the basin, and the Horsepool measurement site is situated within the predominantly natural-gas-producing wells in the eastern half of the basin, as seen in Fig. 1.

The suite of measurements over the three years varied but was very extensive every year, and descriptions can be found in the final reports for the Uintah Basin Ozone Studies on the website of the Utah Department of Environmental Quality (www.deq.utah.gov/locations/U/uintahbasin/ ozone/overview.htm). A brief summary of the ambient gasphase reactive nitrogen measurements is given here. During all three years, $\mathrm{NO}, \mathrm{NO}_{2}, \mathrm{NO}_{3}$, and $\mathrm{N}_{2} \mathrm{O}_{5}$ were measured using cavity ring-down spectroscopy (CRDS), which was also used in conjunction with thermal dissociation (TD-CRDS) to measure $\mathrm{NO}_{y}$ in 2013 and 2014 (Wild et al., 2014). In 2012, $\mathrm{NO}_{y}$ was measured using catalytic conversion to $\mathrm{NO}$ on a gold tube at $325^{\circ} \mathrm{C}$ with subsequent detection using chemiluminescence (CL) via the reaction with $\mathrm{O}_{3}$. Nitric and nitrous acids were measured with an acetate ion chemical ionization mass spectrometer (acid CIMS) all three years. Alkyl nitrates 
Table 1. Measurements of ambient gas-phase reactive nitrogen during UBWOS 2012-2014. The method abbreviations are described in Sect. 2, and LOD refers to the limit of detection. Not all measurements were used in this analysis.

\begin{tabular}{|c|c|c|c|c|c|c|c|}
\hline \multirow{2}{*}{ Species measured } & \multicolumn{3}{|c|}{ Campaign year } & \multirow{2}{*}{ Method } & \multirow{2}{*}{$\begin{array}{r}\text { Accuracy } \\
\%\end{array}$} & \multirow{2}{*}{$\begin{array}{l}\text { LOD } \\
\text { pptv }\end{array}$} & \multirow{2}{*}{ Reference } \\
\hline & 2012 & 2013 & 2014 & & & & \\
\hline $\mathrm{NO}, \mathrm{NO}_{2}, \mathrm{NO}_{3}, \mathrm{~N}_{2} \mathrm{O}_{5}$ & $\mathrm{x}$ & $\mathrm{x}$ & $\mathrm{x}$ & CRDS & $5-10$ & $1-100$ & Wagner et al. (2011) \\
\hline $\mathrm{NO}_{y}$ & $\mathrm{x}$ & & & $\mathrm{CL}$ & 20 & $10-100$ & Williams et al. (1998) \\
\hline $\mathrm{NO}_{y}$ & & $\mathrm{x}$ & $\mathrm{x}$ & TD-CRDS & 10 & 20 & Wild et al. (2014) \\
\hline $\mathrm{HNO}_{3}, \mathrm{HONO}$ & $\mathrm{x}$ & $\mathrm{x}$ & $\mathrm{x}$ & acid CIMS & 30 & 10 & Roberts et al. (2010) \\
\hline Alkyl \& peroxynitrates & $\mathrm{x}$ & & & TD-LIF & 20 & $24-34$ & Day et al. (2002) \\
\hline Acyl peroxynitrates & $\mathrm{x}$ & $\mathrm{x}$ & $\mathrm{x}$ & $\mathrm{I}^{-} \mathrm{CIMS}$ & 20 & 10 & Slusher et al. (2004) \\
\hline $\mathrm{ClNO}_{2}$ & $\mathrm{x}$ & $\mathrm{x}$ & $\mathrm{x}$ & $\mathrm{I}^{-} \mathrm{CIMS}$ & 20 & 5 & Osthoff et al. (2008) \\
\hline $\mathrm{HO}_{2} \mathrm{NO}_{2}$ & & & $\mathrm{x}$ & $\mathrm{I}^{-} \mathrm{CIMS}$ & 20 & 5 & Veres et al. (2015) \\
\hline $\mathrm{NO}_{2}, \mathrm{NO}_{3}, \mathrm{HONO}$ & $\mathrm{x}$ & & $\mathrm{x}$ & LP-DOAS & $3-8$ & $80,2,20$ & Platt and Stutz (2008) \\
\hline $\mathrm{NO}_{2}, \mathrm{HONO}$ & & & $\mathrm{x}$ & ACES & 15 & 200 & Young et al. (2012) \\
\hline HONO & & & $\mathrm{x}$ & LoPAP & 15 & 10 & Heland et al. (2001) \\
\hline
\end{tabular}

and peroxynitrates were only measured in 2012, by thermally dissociating them to $\mathrm{NO}_{2}$ and subsequently detecting them via laser-induced fluorescence (TD-LIF). Acyl peroxynitrates (PANs) and nitryl chloride $\left(\mathrm{ClNO}_{2}\right)$ were measured all three years using an iodide chemical ionization mass spectrometer ( $\left.\mathrm{I}^{-} \mathrm{CIMS}\right)$. Finally, there was extra focus on HONO in 2014, which was measured by a long-path differential optical absorption spectrometer (LP-DOAS), a broadband cavity-enhanced spectrometer (ACES), and a long-path absorption photometer (LoPAP), as well as the acid CIMS and the $\mathrm{I}^{-}$CIMS. The measurements and references for the techniques are summarized in Table 1. Due to the overlap or lack of some measurements in different years, not all the data were utilized in this analysis.

\section{Results}

\subsection{Ozone and reactive nitrogen levels}

In this analysis we focus on analysis of diel profiles, averaged over the duration of each field campaign. This method highlights the general differences between the years but does not distinguish between different meteorological conditions within a campaign. In Fig. 2, we show whole-campaign diel averages of the ozone levels at the Horsepool ground site for the winters of 2012, 2013, and 2014. The dotted line shows the NAAQS level of $75 \mathrm{ppbv}$. On average, ozone levels were 2.5 times higher in 2013 than in 2012. Additionally, ozone production during midday (between the dotted lines at 09:45 and 14:30 mountain standard time) was $2.7 \mathrm{ppbv} \mathrm{h}^{-1}$ in 2012 and $6.9 \mathrm{ppbv} \mathrm{h}^{-1}$ in 2013, a factor of 2.6 higher. In 2014, the ozone levels were intermediate, with the daily increase at $4.8 \mathrm{ppbv} \mathrm{h}^{-1}$. Although the ozone increase is affected by both chemical production and dilution due to the changing boundary layer, chemical ozone production accounts for most of this increase at this site. For 2012, when atmospheric conditions were least stable, chemical production was estimated to
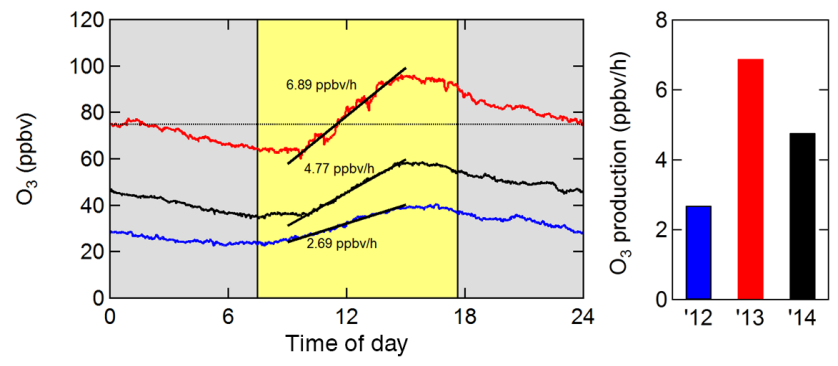

Figure 2. Diel averages of ozone mixing ratios during the campaigns in 2012 (45 days), 2013 (28 days), and 2014 (27 days), and the 75 ppbv NAAQS for reference. Average ozone levels were 2.5 times higher in 2013 than 2012. Linear fits to the midday ozone increase illustrate the difference in average daily ozone production, plotted on the right.

account for $70-85 \%$ of the observed average diel rise in surface $\mathrm{O}_{3}$. These estimates were derived from comparison of the model to the measured surface level rise and from measurements of the diel average $\mathrm{O}_{3}$ profile at different heights up to $500 \mathrm{~m}$ from a tethered balloon. (Edwards et al., 2013).

The top plot in Fig. 3 shows the diurnally averaged total reactive nitrogen $\left(\mathrm{NO}_{y}\right)$. The $\mathrm{NO}_{y}$ in 2013 is on average a factor of 2.5 higher than 2012, with 2014 again at intermediate levels. However, the middle plot of Fig. 3 shows that the total $\mathrm{NO}_{x}$ concentrations are consistently similar for all three years, despite significantly different meteorological conditions and ozone production rates. The bottom plot shows the ratio $\mathrm{NO}_{x} / \mathrm{NO}_{y}$, a measure of the rate of oxidation of reactive nitrogen independent of dilution, whereby a lower ratio implies more oxidation. The large differences in this ratio (a factor of 2.6 on average between 2012 and 2013) instead indicates large differences in levels of $\mathrm{NO}_{x}$ oxidation caused by changes in ambient chemistry, which caused the similarity in $\mathrm{NO}_{x}$ levels between the measurement years. 


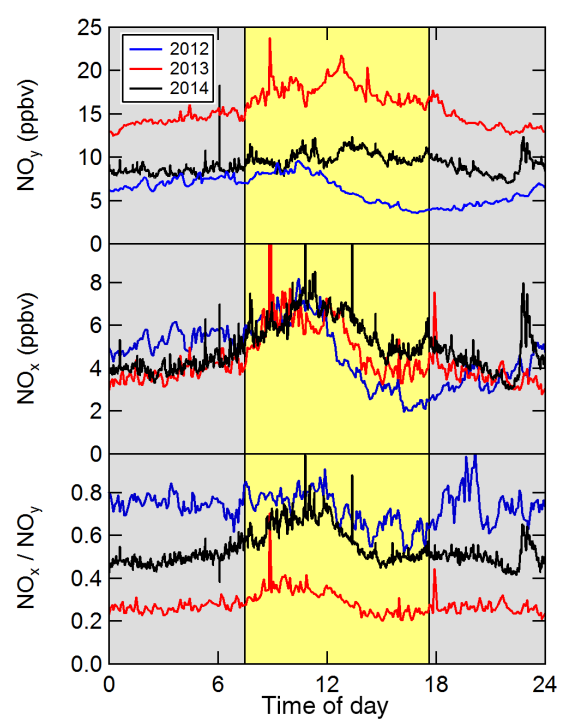

Figure 3. Diel averages of reactive nitrogen. Top: total $\mathrm{NO}_{y}$ was a factor of 2.5 times larger in 2013 than in 2012. Middle: the amount of photochemically active $\mathrm{NO}_{x}$ remained at similar levels all three years. Bottom: the ratio of $\mathrm{NO}_{\mathrm{x}} / \mathrm{NO}_{\mathrm{y}}$, an inverse measure of the level of oxidation of reactive nitrogen, was a factor of 2.6 smaller in 2013 than 2012.

\section{2 $\mathrm{NO}_{y}$ partitioning and $\mathrm{NO}_{x}$ oxidation}

We examine the oxidation pathways and products in order to understand the different levels of $\mathrm{NO}_{x}$ oxidation for the various years. Figure 4 shows the partitioning of $\mathrm{NO}_{z}$ $\left(\equiv \mathrm{NO}_{y}-\mathrm{NO}_{x}\right)$ for 2012 and 2013. In 2012, since $\mathrm{NO}_{x}$ makes up approximately $80 \%$ of $\mathrm{NO}_{y}$, the subtraction to calculate $\mathrm{NO}_{z}$ results in a noisy trace with large uncertainty relative to the amount of $\mathrm{NO}_{z}$ present, and we instead take the sum of components to define total $\mathrm{NO}_{z}$. This is not the case in 2013, and the "missing" part of $\mathrm{NO}_{z}$ is likely organic nitrates $\left(\mathrm{RONO}_{2}\right)$ for which we do not have a measurement.

Ammonium nitrate might be measured partially in the acid CIMS and the $\mathrm{NO}_{y}$ instrument due to heated inlets, and its contribution to $\mathrm{NO}_{z}$ has not been included in this analysis. Measurements of aerosol nitrate, which would include coarse-mode aerosol whose source might not be exclusively photochemical, present an average upper limit of $0.4 \mathrm{ppbv}$ in 2012 and $1 \mathrm{ppbv}$ in 2013. Nitrous acid, HONO, was measured as a small fraction $(2.4 \%)$ of $\mathrm{NO}_{z}$ in 2012. Its mixing ratio was measured by both the acid CIMS and DOAS measurements, which both showed maximum values smaller than 120 pptv average at night and smaller during the day, with agreement to within a factor of 2. During 2013, the acid CIMS was the only measurement available. It showed very large signals at the mass normally interpreted as HONO with a distinct, daytime maximum. As described in Veres et al. (2015), $\mathrm{HO}_{2} \mathrm{NO}_{2}$ mixing ratios were observed to reach an average daytime maximum of approximately $4 \%$ of $\mathrm{NO}_{z}$. Un- published laboratory results suggest that a large fraction of the $\mathrm{HO}_{2} \mathrm{NO}_{2}$ is detected as HONO using the acid CIMS, resulting in a positive daytime bias in the 2013 measurements. Based on the similarity of DOAS HONO measurements in 2012 and 2014, HONO for 2013 was set equal to that from 2012. For further details on comparisons of HONO measurements, please see Edwards et al. (2014).

In 2012, $\mathrm{N}_{2} \mathrm{O}_{5}$ and $\mathrm{ClNO}_{2}$ make up about half of the total $\mathrm{NO}_{z}$ budget at night, whereas they form a small percentage in 2013. Nitric acid $\left(\mathrm{HNO}_{3}\right)$ and PAN, however, make up about $75 \%$ of total $\mathrm{NO}_{z}$ throughout the whole diel cycle in 2013, with the inferred organic nitrates making up most of the remainder. The major oxidation pathways that produce these compounds during the day are

$$
\begin{array}{lr}
\mathrm{NO}_{2}+\mathrm{OH}+\mathrm{M} \longrightarrow & \begin{array}{r}
\mathrm{HNO}_{3}+\mathrm{M}, \\
\mathrm{NO}_{2}+\mathrm{PA}+\mathrm{M} \longrightarrow \\
\mathrm{NO}+\mathrm{RO}_{2}+\mathrm{M} \stackrel{\alpha}{\longrightarrow}
\end{array} \\
\mathrm{PONO}_{2}+\mathrm{M}, \mathrm{M},
\end{array}
$$

where PA is the peroxyacetyl radical and includes all acyl peroxy radicals, with $\mathrm{CH}_{3} \mathrm{C}(\mathrm{O}) \mathrm{O}_{2}$ being the most important. $\mathrm{RO}_{2}$ includes all other organic peroxy radicals, and $\alpha$ is the temperature-dependent yield of organic nitrates from the reaction of organic peroxy radical with $\mathrm{NO}$, where the majority of this reaction produces an alkoxy radical and $\mathrm{NO}_{2}$ (Lee et al., 2014). At night, when $\mathrm{NO}_{3}$ is photochemically stable, the main pathway for $\mathrm{NO}_{x}$ oxidation is

$$
\begin{aligned}
\mathrm{NO}_{2}+\mathrm{O}_{3} \longrightarrow & \mathrm{NO}_{3}+\mathrm{O}_{2}, \\
\mathrm{NO}_{3}+\mathrm{NO}_{2}+\mathrm{M} \longrightarrow & \mathrm{N}_{2} \mathrm{O}_{5}+\mathrm{M} .
\end{aligned}
$$

This $\mathrm{N}_{2} \mathrm{O}_{5}$ can then further react heterogeneously to form nitric acid and nitryl chloride.

$$
\begin{array}{lr}
\mathrm{N}_{2} \mathrm{O}_{5}+\mathrm{H}_{2} \mathrm{O} \stackrel{\text { het }}{\longrightarrow} & 2 \mathrm{HNO}_{3} \\
\mathrm{~N}_{2} \mathrm{O}_{5}+\mathrm{HCl} \stackrel{\text { het }}{\longrightarrow} & \mathrm{HNO}_{3}+\mathrm{ClNO}_{2}
\end{array}
$$

Calculating the reaction rates of Reactions (R1)-(R5) allows us to compare $\mathrm{NO}_{x}$ loss rates (rates of conversion to $\mathrm{NO}_{z}$ ) through these different pathways. The reaction rate constants are known, and the concentrations of $\mathrm{OH}$ and PA are supplied by a box-model simulation using the Master Chemical Mechanism (MCM), as is the production rate of organic nitrates. The MCM utilizes greater than $10^{4}$ reactions, and the base run accurately reproduces an ozone buildup event in 2013 (Edwards et al., 2014). Additionally, the $\mathrm{OH}$ concentrations agree with $\mathrm{OH}$ inferred from VOC ratios (Koss et al., 2015) with average midday maximum $\mathrm{OH}$ levels calculated by the model to be approximately $1 \times 10^{6} \mathrm{~cm}^{-3}$. During the 2012 study, calculated midday $\mathrm{OH}$ was $7 \times 10^{5} \mathrm{~cm}^{-3}$ (Edwards et al., 2013). Although PAN can thermally dissociate, the long lifetime at wintertime temperatures $\left(>10 \mathrm{~h}\right.$ below $\left.10^{\circ} \mathrm{C}\right)$ means we can effectively consider only the forward reaction. The limiting step in Reactions (R4)-(R5) is the $\mathrm{NO}_{2}+\mathrm{O}_{3}$ reaction and we assume 

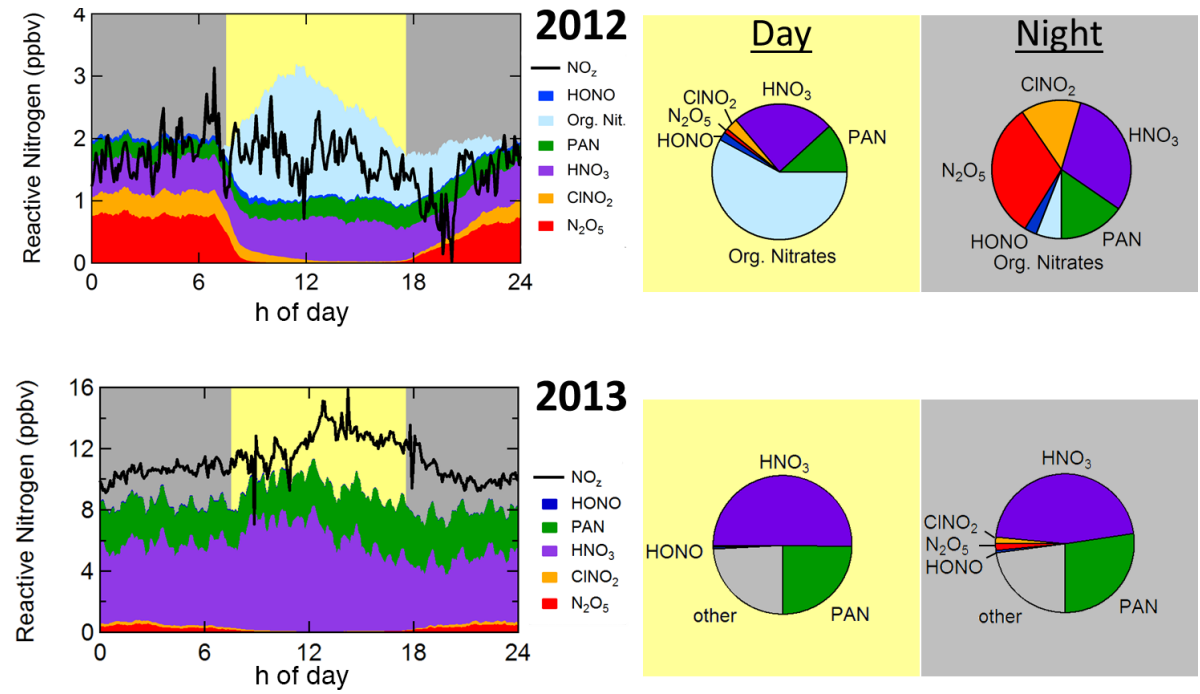

Figure 4. Partitioning among reactive nitrogen species for 2012 and 2013, shown as diel averages (left) as well as daytime and nighttime pie charts (right). We take total $\mathrm{NO}_{z}$ to be the sum of components in 2012, and the difference between $\mathrm{NO}_{y}$ and $\mathrm{NO}_{x}$ in 2013 . The missing $\mathrm{NO}_{z}$ in 2013 (labeled "other" in the pie charts) is likely organic nitrates, for which we do not have measurements in 2013. In 2012, daytime organic nitrates and nighttime $\mathrm{N}_{2} \mathrm{O}_{5}$ and $\mathrm{ClNO}_{2}$ play an important role compared to 2013, where total $\mathrm{PANs}$ and $\mathrm{HNO}_{3}$ are the largest contributors to $\mathrm{NO}_{z}$.

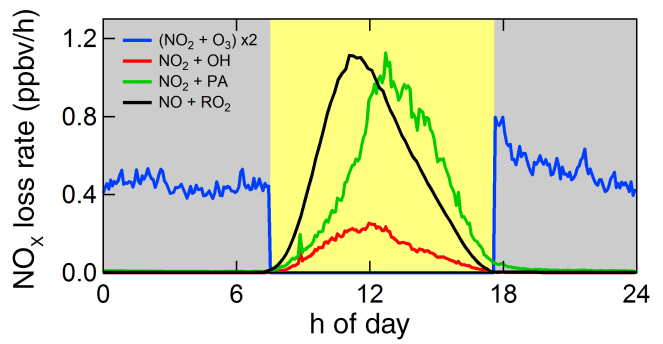

Figure 5. Daytime and nighttime loss rates of $\mathrm{NO}_{x}$ in 2013 through the major oxidation pathways. Concentrations of $\mathrm{OH}$ and $\mathrm{PA}$ and the production rate of organic nitrates $\left(\mathrm{NO}+\mathrm{RO}_{2}\right)$ were supplied by the Master Chemical Mechanism box model used by Edwards et al. (2013). The daytime $\mathrm{NO}_{3}$ production is set to zero because of the fast $\mathrm{NO}_{3}$ photolysis and reaction with photochemically generated NO, and doubled at night due to Reaction (R5). The integrated nighttime loss toward $\mathrm{HNO}_{3}$ is 5.9 times greater than during the day.

that the sequence of reactions in Reactions (R4)-(R7) quantitatively converts $\mathrm{NO}_{2}$ to stable products, mainly $\mathrm{HNO}_{3}$, at night in 2013 (we calculate $\mathrm{N}_{2} \mathrm{O}_{5}$ lifetimes to be $<2 \mathrm{~h}$; see below). The $\mathrm{NO}_{x}$ loss rate due to Reaction (R4) is doubled, because the sum of Reactions (R4) and (R5) would lead to $\mathrm{NO}_{x}$ loss at twice the rate of Reaction (R4). The reaction pathway to make $\mathrm{N}_{2} \mathrm{O}_{5}$ is negligible during daylight hours due to photodissociation of $\mathrm{NO}_{3}$ together with the fast reaction of $\mathrm{NO}_{3}$ with $\mathrm{NO}$, and has been set to zero. The resulting $2013 \mathrm{NO}_{x}$ loss rates due to Reactions (R1)-(R5) are shown in Fig. 5.
Separating the daytime and nighttime partitioning in Fig. 4 highlights the species that are long-lived at night and shortlived during the day $\left(\mathrm{N}_{2} \mathrm{O}_{5}\right.$ and $\left.\mathrm{ClNO}_{2}\right)$, demonstrating the role of the nighttime species in reactive nitrogen chemistry. Nitric acid, PAN, and organic nitrates, on the other hand, are long-lived compared to a diel cycle, and we do not expect the nighttime or daytime average to reflect chemical production that is restricted to these periods. It instead represents an average not just over a diel cycle but over the whole campaign.

Integrating the diurnally averaged loss rates gives total daily calculated production of the three major components of $\mathrm{NO}_{z}$, with the simplifying assumption that all $\mathrm{N}_{2} \mathrm{O}_{5}$ is converted to nitric acid (we estimate the $\mathrm{ClNO}_{2}$ yield for 2012 and 2013 to be 11 and $2 \%$, respectively). In Fig. 6 we compare the partitioning of these integrated production rates with the measured partitioning of $\mathrm{HNO}_{3}$, PAN, and inferred organic nitrates for 2013. Production rates and observed concentrations should not necessarily be proportional, depending on the loss mechanisms. For example, $\mathrm{HNO}_{3}$ will be lost via dry deposition to the ground or snow surface such that its measured contribution to nitrogen partitioning may be smaller than that inferred from its production rate. However, the agreement between production rates and observations illustrates that our methods of treating the reactive nitrogen in the current analysis and in the MCM box model are selfconsistent.

Reactions (R1) and (R4)-(R7) result in formation of $\mathrm{HNO}_{3}$, which makes up the bulk of $\mathrm{NO}_{z}$ in 2013. Furthermore, the integrated nighttime loss toward nitric acid is 5.9 times greater than during the day. Therefore much of the difference in $\mathrm{NO}_{z}$ between the low-ozone year of 2012 and the 

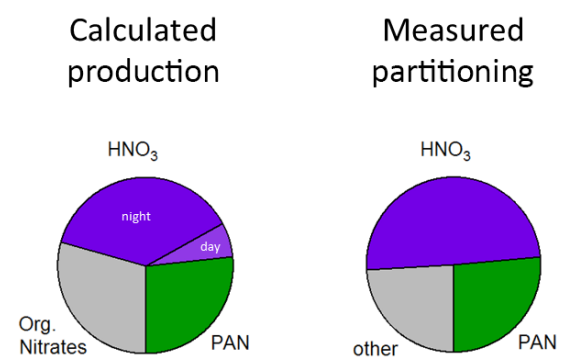

Figure 6. Comparison of the relative importance in 2013 of calculated oxidized reactive nitrogen production rates to the measured $\mathrm{NO}_{z}$ partitioning for the three largest components of $\mathrm{NO}_{z}$. On the right chart, "other" refers to the missing $\mathrm{NO}_{z}$ which we attribute to the unmeasured organic nitrates.

high-ozone year of 2013 must be due to a large difference in nighttime $\mathrm{N}_{2} \mathrm{O}_{5}$ reactivity, which we analyze below.

\section{$3.3 \quad \mathrm{~N}_{2} \mathrm{O}_{5}$ lifetimes}

When the sinks of $\mathrm{NO}_{3}$ are small compared to those of $\mathrm{N}_{2} \mathrm{O}_{5}$, and assuming an equilibrium state between $\mathrm{NO}_{2}, \mathrm{NO}_{3}$, and $\mathrm{N}_{2} \mathrm{O}_{5}$, the ratio of the $\mathrm{N}_{2} \mathrm{O}_{5}$ concentration to the production rate of $\mathrm{NO}_{3}$ equals the $\mathrm{N}_{2} \mathrm{O}_{5}$ lifetime $\left(\tau_{\mathrm{N}_{2} \mathrm{O}_{5}}\right)$,

$\tau_{\mathrm{N}_{2} \mathrm{O}_{5}}=\frac{\left[\mathrm{N}_{2} \mathrm{O}_{5}\right]}{k \cdot\left[\mathrm{NO}_{2}\right] \cdot\left[\mathrm{O}_{3}\right]}$,

where $k$ is the rate coefficient for Reaction (R4) (Brown et al., 2003). An analysis of the resulting lifetimes, which can be considered a measure of $\mathrm{N}_{2} \mathrm{O}_{5}$ reactivity, is shown with the solid lines in Fig. 7. Since Eq. (1) assumes a steady state in $\mathrm{NO}_{3}$ and $\mathrm{N}_{2} \mathrm{O}_{5}$, the relevant period when this lifetime interpretation will be most valid is at the end of the night. However, a simple five-reaction chemical box model including $\mathrm{NO}_{3}$ and $\mathrm{N}_{2} \mathrm{O}_{5}$ production and first-order loss (Brown et al., 2003) shows that it would take $>20 \mathrm{~h}$ to reach a steady state in 2012. After the $14 \mathrm{~h}$ of night, we predict that the lifetime calculated using Eq. (1) gives us $77 \%$ of the actual lifetime. In 2013, the model predicts that the system reaches $90 \%$ of steady state in $1.8 \mathrm{~h}$. The lifetimes in 2012 are a factor of approximately 2 times longer than in 2013, or 2.6 times if we use calculated equilibrium values. McLaren et al. (2010) have suggested an alternate method for lifetime analysis that explicitly takes the time derivative of $\mathrm{N}_{2} \mathrm{O}_{5}$ into account to correct its lifetime for failure to reach steady state. Figure 7 also shows the steady-state lifetime calculated using this method using a smooth fit function for the $\mathrm{N}_{2} \mathrm{O}_{5}$ diel profile to calculate the derivative. Since the reaction of $\mathrm{N}_{2} \mathrm{O}_{5}$ occurs heterogeneously via uptake onto surfaces, the difference in lifetime between the two years could conceivably be due to higher aerosol surface area or faster ground deposition. The average value of the product of the $\mathrm{NO}_{3}-\mathrm{N}_{2} \mathrm{O}_{5}$ equilibrium constant, $K_{\text {eq }}(T)$, and the $\mathrm{NO}_{2}$ concentration $\left(K_{\text {eq }}\left[\mathrm{NO}_{2}\right]\right)$, equal to the predicted ratio of $\mathrm{N}_{2} \mathrm{O}_{5}$ to $\mathrm{NO}_{3}$, was 115 and 440

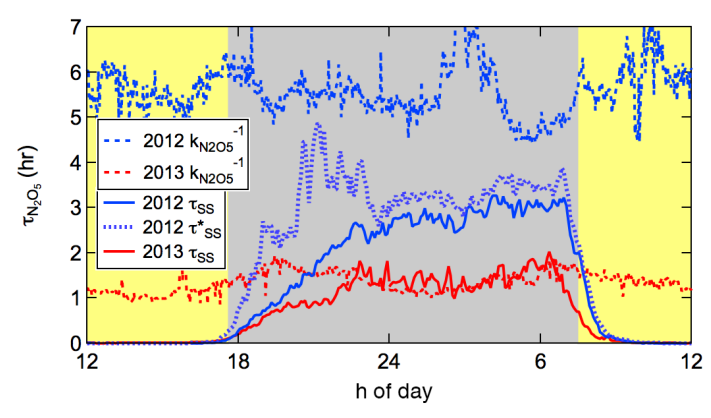

Figure 7. Lifetimes of $\mathrm{N}_{2} \mathrm{O}_{5}$, calculated using the production rate of $\mathrm{NO}_{3}$ (solid lines), the lifetime calculated using the method of McLaren et al. (2010) for 2012 (short dashed line; see text), and uptake to aerosol using an uptake coefficient of $\gamma=0.02$ (dashed lines). In 2012 we expect that the calculation gives $77 \%$ of the actual lifetime, due to the system not reaching equilibrium at the end of the night. The McLaren method, based on explicit inclusion of the time derivative for $\mathrm{N}_{2} \mathrm{O}_{5}$, partially corrects for this effect, especially early in the night. An uptake coefficient of $\gamma=0.026$ would bring the $\mathrm{P}\left(\mathrm{NO}_{3}\right)$ and aerosol calculations in 2012 into agreement. The observed lifetimes from $\mathrm{P}\left(\mathrm{NO}_{3}\right)$ include deposition, but the calculated curves do not.

during nighttime hours in 2012 and 2013, respectively. Late night average $\mathrm{NO}_{3}$ of $2.2 \mathrm{pptv}$ agreed well with the predicted equilibrium. Average predicted $\mathrm{NO}_{3}$ of less than $0.5 \mathrm{pptv}$ in 2013 could not be accurately measured. The late night average steady-state lifetime of $\mathrm{NO}_{3}$ in 2012 was approximately $100 \mathrm{~s}$, while in 2013 it was $13 \mathrm{~s}$. Under these cold conditions, the very short $\mathrm{NO}_{3}$ lifetimes do not represent the reactivity of the $\mathrm{NO}_{3}-\mathrm{N}_{2} \mathrm{O}_{5}$ system, which is dominated by heterogeneous loss of $\mathrm{N}_{2} \mathrm{O}_{5}$, and we provide them here for reference only.

Lifetimes due to aerosol can be calculated separately using measurements of aerosol surface area and the equation for heterogeneous uptake, assuming no limitation for gas phase diffusion (valid for small particle size and small to moderate uptake coefficients, and consistent with conditions from both 2012 and 2013):

$\tau_{\mathrm{N}_{2} \mathrm{O}_{5}}=\left(\frac{1}{4} \gamma \bar{c} S_{\mathrm{A}}\right)^{-1}$

where $\gamma$ is the uptake coefficient, $\bar{c}$ the mean molecular speed, and $S_{\mathrm{A}}$ the surface area density of the aerosol. The aerosol surface area density was calculated from number size distributions measured using a scanning mobility particle sizer for particles between 20 and $500 \mathrm{~nm}$ geometric diameter, and a aerodynamic particle sizer for particles between 0.7 and $10.37 \mu \mathrm{m}$. Size distribution measurements were taken at relative humidity $<25 \%$, and a hygroscopic growth factor was calculated using measurements of ambient humidity and aerosol composition (Bates et al., 2002). There are few determinations of $\mathrm{N}_{2} \mathrm{O}_{5}$ uptake coefficients in winter. During winter measurements in Colorado, Wagner et al. (2013) 


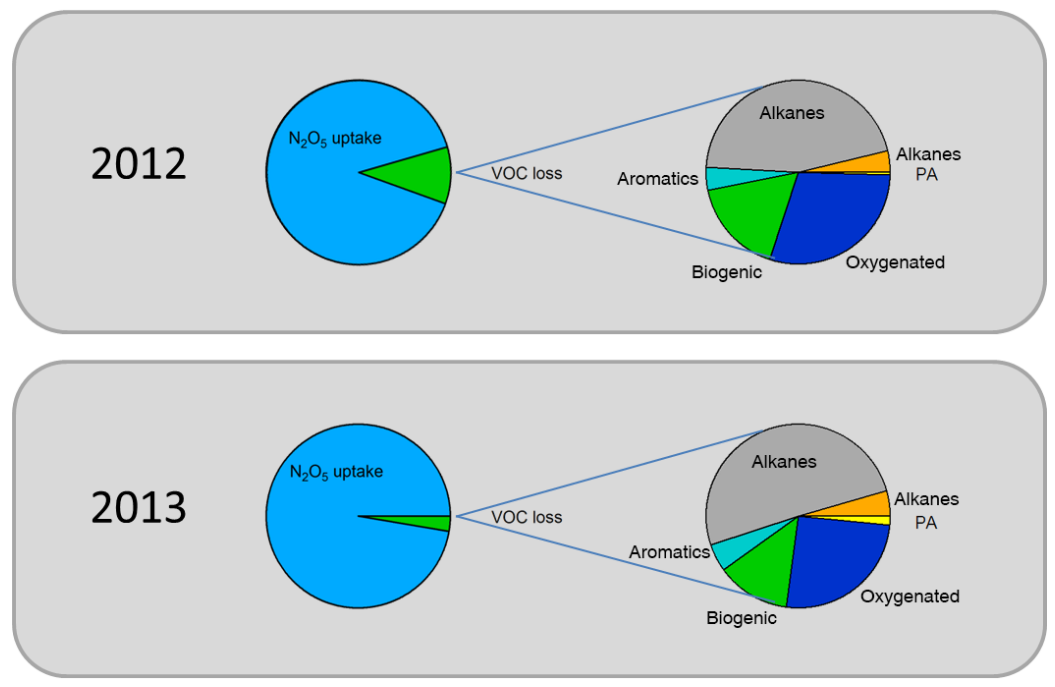

Figure 8. Contributions to $\mathrm{NO}_{3}$ reactivity. In both years, formation of $\mathrm{N}_{2} \mathrm{O}_{5}$ and consequent uptake to aerosol dominate $\mathrm{NO}_{3}$ loss, and reactions with VOCs are primarily with alkanes. For comparison, the total $\mathrm{NO}_{3}$ loss rate was $0.016 \mathrm{~s}^{-1}$ in 2012 and $0.118 \mathrm{~s}^{-1}$ in 2013 .

determined an average $\gamma=0.02$ under similar conditions of temperature and relative humidity, and at a site with nearly identical latitude and elevation. Using $\gamma=0.02$, we calculate the lifetimes of $\mathrm{N}_{2} \mathrm{O}_{5}$ due to aerosol uptake for 2012 and 2013, plotted as dashed lines in Fig. 7. The 2012 lifetime includes a $10 \%$ correction from the contribution of losses due to VOCs (see below). On average, lifetimes calculated from aerosol uptake were a factor of 4.1 higher in 2012 than 2013, compared to the factor of 2.6 change in lifetime calculated from the $\mathrm{N}_{2} \mathrm{O}_{5}$ steady state of Eq. (1) and the box model. However, an uptake factor of $\gamma=0.026$ in 2012 would bring the lifetimes calculated using these two methods into agreement. Since we did not perform eddy covariance flux measurements, we do not know the deposition rate, and the $\gamma$ values derived from comparison to the steady-state lifetimes thus represent an upper limit. Additionally, since the lifetime of $\mathrm{N}_{2} \mathrm{O}_{5}$ is longer in 2012, the influence of deposition to the ground surface might be greater if it were roughly constant relative to other sinks that increased between 2012 and 2013. The change in aerosol uptake between the two years is in part due to the higher relative humidity measured in 2013, which increased the aerosol surface area through hygroscopic growth. The increased relative humidity in 2013 caused frequent and persistent fog. Due to the difficulty in extrapolating a hygroscopic growth factor near saturation, data during periods of relative humidity above $95 \%$ have been excluded in this analysis. Hygroscopic growth associated with the higher relative humidity contributed a factor of approximately 1.3 to the difference in lifetime between the two years.

One condition of Eq. (1) is that the major sink of $\mathrm{NO}_{3}$ is through aerosol uptake via $\mathrm{N}_{2} \mathrm{O}_{5}$ instead of reactions with volatile organic compounds (VOCs). Previous studies in regionally polluted areas have shown that loss of $\mathrm{NO}_{3}$ and
$\mathrm{N}_{2} \mathrm{O}_{5}$ can be dominated by $\mathrm{NO}_{3}-\mathrm{VOC}$ reactions, $\mathrm{N}_{2} \mathrm{O}_{5}$ uptake, or a combination of the two (Aldener et al., 2006; Brown et al., 2011). Given the high VOC concentrations in the Uintah Basin (Helmig et al., 2014), we performed an analysis of $\mathrm{NO}_{3}$ reactivity to quantify the contribution of $\mathrm{NO}_{3}$ chemistry to the lifetime of $\mathrm{N}_{2} \mathrm{O}_{5}$. The loss due to VOC is simply the sum of all the $\mathrm{NO}_{3}-\mathrm{VOC}$ rate constants $\left(k_{i}\right)$ times the measured VOC concentrations

$k_{\text {loss }}\left(\mathrm{NO}_{3}\right)=\sum_{i} k_{i}\left[\mathrm{VOC}_{i}\right]$.

This first-order loss rate coefficient for $\mathrm{NO}_{3}$ can be compared to the first-order loss rate coefficient for uptake of $\mathrm{N}_{2} \mathrm{O}_{5}$ to aerosol by dividing the former by the equilibrium ratio of $\mathrm{N}_{2} \mathrm{O}_{5} / \mathrm{NO}_{3}$ (Brown et al., 2003). VOC measurements by proton transfer reaction mass spectrometry and gas chromatography in 2012 provided measurements of a more extensive VOC suite than the measurements in 2013, so VOC ratios from 2012 were used to estimate some compounds missing from 2013 measurements, as was done by Edwards et al. (2013). The calculations show that with an $\mathrm{N}_{2} \mathrm{O}_{5}$ uptake coefficient of $0.02, \mathrm{NO}_{3}$ losses due to reactions with VOCs were approximately 10 times less than $\mathrm{N}_{2} \mathrm{O}_{5}$ uptake to aerosol in 2012, and approximately 40 times less in 2013. A lower $\mathrm{N}_{2} \mathrm{O}_{5}$ uptake coefficient would increase the fraction of the $\mathrm{NO}_{3}$ and $\mathrm{N}_{2} \mathrm{O}_{5}$ reactivity attributable to $\mathrm{NO}_{3}-$ VOC chemistry. However, the comparisons of Fig. 7 suggest that the average $\mathrm{N}_{2} \mathrm{O}_{5}$ uptake coefficient is not appreciably smaller than 0.02. Figure 8 shows the relative loss rates, as well as the breakdown of reactivity with different classes of VOCs. During both years, reactivity with alkanes form the major part of $\mathrm{NO}_{3}$ loss to VOCs (45-51\%). To our knowledge, this is the first instance in which alkanes have been determined as the largest single component of $\mathrm{NO}_{3}-\mathrm{VOC}$ reac- 
tivity in ambient air. For example, studies in other locations, such as Houston, Texas, show that alkanes contribute approximately $1 \%$ to ambient $\mathrm{NO}_{3}$ reactivity (Brown et al., 2011). Despite their very slow rate constants for reaction with $\mathrm{NO}_{3}$, alkanes make up an overwhelming fraction of the measured VOC composition in the Uintah Basin, leading to an unusually large contribution to $\mathrm{NO}_{3}$ reactivity. Isoprene and dimethyl sulfide (DMS) are collectively labeled "biogenic" according to convention, but due to winter conditions we anticipate no biogenic source for these compounds. Rather, we assume both to be emissions from oil and gas operations. For example, an anthropogenic source of isoprene may be emitted in small quantities in vehicle exhaust (McLaren et al., 1996), while DMS may be a component of the reduced sulfur emissions from natural gas. In any case, the measured concentrations of both compounds are small ( 2 and $0.7 \mathrm{pptv}$, respectively, nighttime average in 2013), and their contribution to $\mathrm{NO}_{3}$ reactivity represents the fast $\mathrm{NO}_{3}$ rate constant with these species. It is possible that other highly reactive but unmeasured VOCs contribute to the $\mathrm{NO}_{3}$ reactivity. For example, Crowley et al. (2011) report an important role for reduced sulfur species other than DMS in loss of $\mathrm{NO}_{3}$ radicals near an oil refinery. Such measurements were unavailable for the UBWOS studies.

Since $\mathrm{N}_{2} \mathrm{O}_{5}$ uptake to the ground can also affect lifetimes, one has to consider differences in inlet height and ground composition between different years. In 2012, $\mathrm{N}_{2} \mathrm{O}_{5}$ was measured from a scaffold tower at a height of $11 \mathrm{~m}$, whereas in 2013, the lack of such a tower limited the sampling height to $4 \mathrm{~m}$. To investigate a possible $\mathrm{N}_{2} \mathrm{O}_{5}$ gradient, we alternately sampled from 14 and $1 \mathrm{~m}$ during the final weeks of the 2014 campaign, spanning the sample heights of the 2012 and 2013 inlets. In 2014, the ground was snow-covered, and conditions generally resembled 2013 more than 2012. The resulting lifetime calculations using $\mathrm{NO}_{3}$ production rates (Eq. 1) are shown in Fig. 9 with black solid and dotted lines. We measured roughly twice the $\mathrm{N}_{2} \mathrm{O}_{5}$ lifetime at the high inlet as compared to the low inlet. This difference results solely from differences in $\mathrm{N}_{2} \mathrm{O}_{5}$ concentrations; measurements of $\mathrm{NO}_{2}, \mathrm{O}_{3}$, and aerosol surface area between 4 and $14 \mathrm{~m}$ did not show significant differences at night and were assumed to be equal for the lifetime calculation. Ground deposition of $\mathrm{N}_{2} \mathrm{O}_{5}$ can form an important contribution to the lifetime (Huff et al., 2011; Kim et al., 2014), but the year-toyear variability is a significantly larger effect than the measured $\mathrm{N}_{2} \mathrm{O}_{5}$ gradient. This suggests that nighttime aerosol uptake of $\mathrm{N}_{2} \mathrm{O}_{5}$ could play a major role in $\mathrm{NO}_{x}$ oxidation and contributes to keeping $\mathrm{NO}_{x}$ levels similar between the three years.

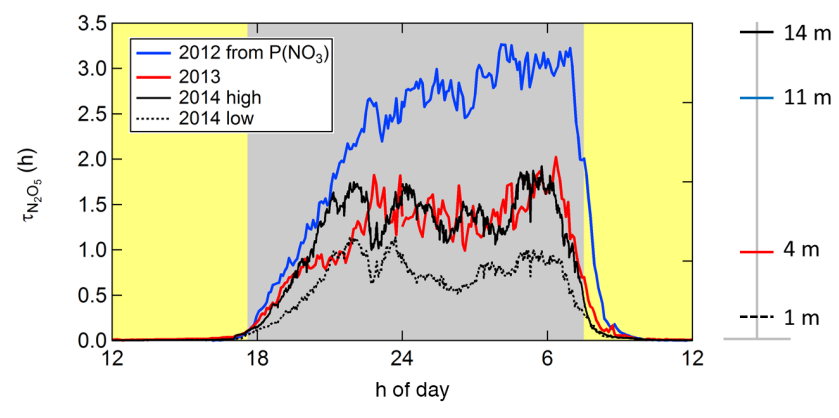

Figure 9. The effect of inlet height on calculated lifetimes. Red and blue lines are the same as in Fig. 7. Black lines are calculated from 2014 measurements with the solid line from an inlet at $14 \mathrm{~m}$ and the dashed line from an inlet at $1 \mathrm{~m}$. These inlet heights span the inlets in 2012 at $11 \mathrm{~m}$ and 2013 at $4 \mathrm{~m}$.

\section{Sensitivity of $\mathrm{NO}_{x}$ and $\mathrm{O}_{3}$ to $\mathrm{NO}_{x}$ oxidation pathways}

We again used the MCM box-model simulation to investigate the relative sensitivities of nitrogen oxide loss and $\mathrm{O}_{3}$ production rates to some of the different $\mathrm{NO}_{x}$ oxidation pathways discussed above. We increased/decreased the reaction rate constants of Reactions (R1) $\left(\mathrm{NO}_{2}+\mathrm{OH}\right),(\mathrm{R} 2)\left(\mathrm{NO}_{2}+\right.$ $\mathrm{PA})$, and (R4) $\left(\mathrm{NO}_{2}+\mathrm{O}_{3}\right)$ by a factor of 2 , keeping all else equal, and compared the resulting $\mathrm{NO}_{x}$ and ozone levels after the model stabilized to the base simulation results that matched observations. The base simulation included a continuous source of $\mathrm{NO}_{x}$, tuned to match observed levels (Edwards et al., 2014). In the MCM, the rate of Reaction (R6) was set empirically to match the observed $\mathrm{N}_{2} \mathrm{O}_{5}$ concentrations. The resulting rate was fast enough that Reaction (R4) was the rate-limiting step in the reaction pathway Reactions (R4)-(R7), and was therefore used to test the sensitivity of that pathway.

The results are shown in Fig. 10, with the left panel showing the final day of the simulation, and the right panel comparing the final day's $24 \mathrm{~h}$ averages. For Reactions (R1) and (R2), an increased/decreased rate has very little effect on $\mathrm{NO}_{x}$ once the model has stabilized. The nighttime pathway has a much larger effect, however, and an doubled rate leads to a $28 \% \mathrm{NO}_{x}$ reduction. Halving the rate causes a $43 \%$ increase. During the day, changing the rate of Reaction (R4) has no effect due to the fast photodissociation of $\mathrm{NO}_{3}$. The response of $\mathrm{O}_{3}$ concentrations is also shown, with the nighttime reactions having the greatest effect. Changing PAN and $\mathrm{HNO}_{3}$ production have comparable effects on ozone even though the effective $\mathrm{NO}_{x}$ removal rates are approximately 4 times different. This may be because the $\mathrm{OH}+\mathrm{NO}_{2}$ affects the propagation of the $\mathrm{HO}_{x}$ cycle directly with $\mathrm{OH}$ reacting with either $\mathrm{NO}_{2}$ or a VOC. PAN production, on the other hand, has its effect based on whether PA reacts with NO or $\mathrm{NO}_{2}$, which scales as the ratio of PA loss to $\mathrm{NO}$ vs. loss to $\mathrm{NO}_{2}$. 

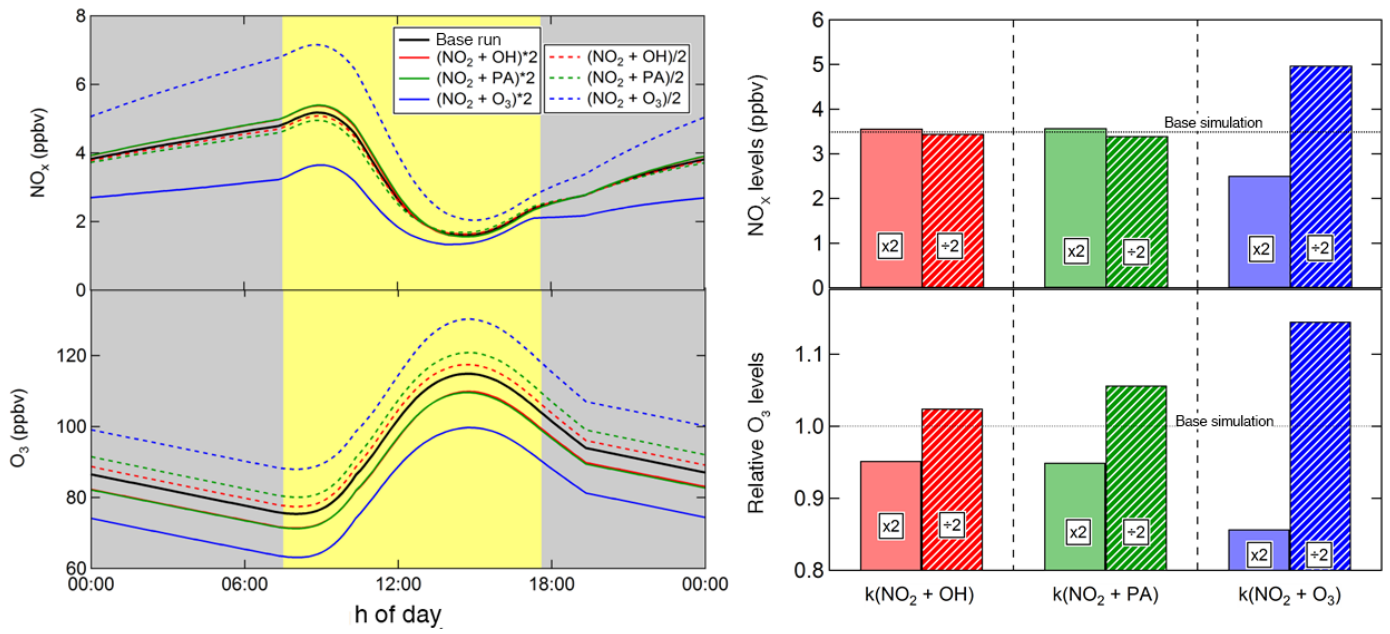

Figure 10. The effect on $\mathrm{NO}_{x}$ and ozone concentration of changing the rates of select reactions in a box-model simulation. The reaction $\mathrm{NO}_{2}+\mathrm{O}_{3}$ represents the nighttime reaction pathway to $\mathrm{HNO}_{3}$.

Although organic nitrates are the largest photochemical pathway for nitrogen loss, we did not perform an analogous simulation using Reaction (R3) $\left(\mathrm{NO}+\mathrm{RO}_{2}\right)$. Since a comparable simulation involves changing all the rate coefficients for a large number of reactions, performing these simulations is beyond the scope of this paper. However, if we scale the sensitivity of doubling/halving the reaction rates for organic nitrate production to the sensitivity to daytime production of nitric acid (a factor of 4.6), we get a change in $\mathrm{NO}_{x}$ of approximately $7 \%$ and a change in $\mathrm{O}_{3}$ of approximately $17 \%$. The effect could be larger since $\mathrm{NO}_{x}$ is higher in the morning, when the $\mathrm{RO}_{2}+\mathrm{NO}$ rate is largest. Scaling it to PAN production (Reaction $\mathrm{R} 2$ ) causes a change in $\mathrm{NO}_{x}$ and $\mathrm{O}_{3}$ of approximately 3 and $6 \%$, respectively. If instead we were to scale $\alpha$ by a factor of 2 , the effect could be larger since there is no competition for the fate of $\mathrm{RO}_{2}$; every $\mathrm{RO}_{2}$ reacts with NO. For example, Lee et al. (2014) found that a $50 \%$ increase in $\alpha$ results in a $7 \mathrm{ppb}$ decrease in ozone (at an ozone concentration of $\sim 60 \mathrm{ppbv}$ ), and they estimate a $25 \mathrm{ppbv}$ effect (at $\sim 140$ ppbv ozone) for conditions with higher $J$ values and slower mixing. Thus, although organic nitrate production should have the largest influence of the photochemical $\mathrm{NO}_{x}$ loss mechanisms on both $\mathrm{NO}_{x}$ and $\mathrm{O}_{3}$, we anticipate that it still has a smaller effect on $\mathrm{NO}_{x}$ loss pathways than the nighttime chemistry in this winter environment.

Winter $\mathrm{O}_{3}$ should be more sensitive to $\mathrm{N}_{2} \mathrm{O}_{5}$ chemistry because it is predominant during winter conditions, with low primary radical generation during daytime and longer duration of darkness. The majority of polluted winter conditions do not produce $\mathrm{O}_{3}$ efficiently due to low photochemical radical production rates. These systems are typically $\mathrm{NO}_{x}$ saturated (Edwards et al., 2013, 2014; Kleinman, 2005). The result of $\mathrm{N}_{2} \mathrm{O}_{5}$ chemistry in most of these situations would be to increase $\mathrm{O}_{3}$ photochemistry during the daytime by reducing the $\mathrm{NO}_{x}$ levels overnight. In summertime urban environ- ments, $\mathrm{N}_{2} \mathrm{O}_{5}$ chemistry should have an effect, but it would be smaller because it will consume a smaller fraction of reactive nitrogen compared especially to Reaction (R1) in more typical summertime ozone photochemical systems. Its effect on $\mathrm{O}_{3}$ will be highly sensitive to the $\mathrm{O}_{3}-\mathrm{NO}_{x}$ sensitivity in any given region, and would be difficult to generalize.

The influence of $\mathrm{ClNO}_{2}$ production from $\mathrm{N}_{2} \mathrm{O}_{5}$ is not explicitly considered here, and was determined to be a small effect on $\mathrm{NO}_{x}$ due to its low yield. However, it may be an important effect on $\mathrm{O}_{3}$ production in other regions during both summer and winter, especially if $\mathrm{ClNO}_{2}$ photolysis is a larger contribution to photochemical radicals than was determined for the UBWOS 2013 study.

\section{Conclusions}

The measurements at Horsepool in the Uintah Basin, Utah, during the winters of 2012, 2013, and 2014 and subsequent modeling provide much insight into the fate of reactive nitrogen and its relationship to ozone production in the basin. Ozone levels were highly elevated in 2013 compared to 2012 , with 2.5 times more ozone on average and 20 out of the 28 days of the measurements at Horsepool experiencing exceedances of the $75 \mathrm{ppbv} 8 \mathrm{~h}$ average daily maximum NAAQS. Total reactive nitrogen, $\mathrm{NO}_{y}$, was 2.5 times more concentrated in 2013 , yet photochemically active $\mathrm{NO}_{x}$ concentrations were approximately equal all three years. This resulted from very different rates of $\mathrm{NO}_{x}$ oxidation leading to much higher concentrations of $\mathrm{HNO}_{3}$, PAN, and missing $\mathrm{NO}_{y}$, presumed to be organic nitrates, with $\mathrm{HNO}_{3}$ making up the largest part of the $\mathrm{NO}_{z}$ budget. Much of the $\mathrm{HNO}_{3}$ formed during the night, with integrated $\mathrm{NO}_{2}$ loss toward $\mathrm{HNO}_{3}$ approximately 6 times higher at night than during the day. At night, $\mathrm{HNO}_{3}$ is produced via heterogeneous uptake 
of $\mathrm{N}_{2} \mathrm{O}_{5}$ onto aerosol, and calculations using measurements of aerosol surface area reproduce the differences in lifetime as calculated using $\mathrm{NO}_{3}$ production rates. Some of the $\mathrm{N}_{2} \mathrm{O}_{5}$ is lost to ground deposition, but aerosol uptake forms a major component of $\mathrm{HNO}_{3}$ formation. A box-model simulation confirms that the nighttime $\mathrm{N}_{2} \mathrm{O}_{5}$ heterogeneous reactions play a significant role in $\mathrm{NO}_{x}$ chemistry and related ozone production.

Acknowledgements. The Uintah Basin Winter Ozone Studies were a joint project led and coordinated by the Utah Department of Environmental Quality (UDEQ) and supported by the Uintah Impact Mitigation Special Service District (UIMSSD), the Bureau of Land Management (BLM), the Environmental Protection Agency (EPA), and Utah State University. This work was funded in part by the Western Energy Alliance, and NOAA's Atmospheric Chemistry, Carbon Cycle and Climate program. We thank Questar Energy Products for site preparation and support. This is PMEL contribution number 4353.

Edited by: N. M. Donahue

\section{References}

Aldener, M., Brown, S. S., Stark, H., Williams, E. J., Lerner, B. M., Kuster, W. C., Goldan, P. D., Quinn, P. K., Bates, T. S., Fehsenfeld, F. C., and Ravishankara, A. R.: Reactivity and loss mechanisms of $\mathrm{NO}_{3}$ and $\mathrm{N}_{2} \mathrm{O}_{5}$ in a polluted marine environment: Results from in situ measurements during New England Air Quality Study 2002, J. Geophys. Res.-Atmos., 111, 2156-2202, 2006.

Bates, T. S., Coffman, D. J., Covert, D. S., and Quinn, P. K.: Regional marine boundary layer aerosol size distributions in the Indian, Atlantic, and Pacific Oceans: A comparison of INDOEX measurements with ACE-1, ACE-2, and Aerosols99, J. Geophys. Res.-Atmos., 107, 8026, doi:10.1029/2001JD001174, 2002.

Brown, S. S., Stark, H., and Ravishankara, A. R.: Applicability of the steady state approximation to the interpretation of atmospheric observations of $\mathrm{NO}_{3}$ and $\mathrm{N}_{2} \mathrm{O}_{5}$, J. Geophys. Res.Atmos., 108, 4539, doi:10.1029/2003JD003407, 2003.

Brown, S. S., Dubé, W. P., Peischl, J., Ryerson, T. B., Atlas, E., Warneke, C., de Gouw, J. A., te Lintel Hekkert, S., Brock, C. A., Flocke, F., Trainer, M., Parrish, D. D., Feshenfeld, F. C., and Ravishankara, A. R.: Budgets for nocturnal VOC oxidation by nitrate radicals aloft during the 2006 Texas Air Quality Study, J. Geophys. Res.-Atmos., 116, D24305, doi:10.1029/2011JD016544, 2011.

Carter, W. P. and Seinfeld, J. H.: Winter ozone formation and VOC incremental reactivities in the Upper Green River Basin of Wyoming, Atmos. Environ., 50, 255-266, 2012.

Crowley, J. N., Thieser, J., Tang, M. J., Schuster, G., Bozem, H., Beygi, Z. H., Fischer, H., Diesch, J.-M., Drewnick, F., Borrmann, S., Song, W., Yassaa, N., Williams, J., Pöhler, D., Platt, U., and Lelieveld, J.: Variable lifetimes and loss mechanisms for $\mathrm{NO}_{3}$ and $\mathrm{N}_{2} \mathrm{O}_{5}$ during the DOMINO campaign: contrasts between marine, urban and continental air, Atmos. Chem. Phys., 11, 10853-10870, doi:10.5194/acp-11-10853-2011, 2011.
Day, D. A., Wooldridge, P. J., Dillon, M. B., Thornton, J. A., and Cohen, R. C.: A thermal dissociation laser-induced fluorescence instrument for in situ detection of $\mathrm{NO}_{2}$, peroxy nitrates, alkyl nitrates, and $\mathrm{HNO}_{3}$, J. Geophys. Res.-Atmos., 107, ACH4.1ACH4.14, 2002.

Edwards, P. M., Young, C. J., Aikin, K., deGouw, J., Dubé, W. P., Geiger, F., Gilman, J., Helmig, D., Holloway, J. S., Kercher, J., Lerner, B., Martin, R., McLaren, R., Parrish, D. D., Peischl, J., Roberts, J. M., Ryerson, T. B., Thornton, J., Warneke, C., Williams, E. J., and Brown, S. S.: Ozone photochemistry in an oil and natural gas extraction region during winter: simulations of a snow-free season in the Uintah Basin, Utah, Atmos. Chem. Phys., 13, 8955-8971, doi:10.5194/acp-13-8955-2013, 2013.

Edwards, P. M., Brown, S. S., Roberts, J. M., Ahmadov, R., Banta, R. M., deGouw, J. A., Dubé, W. P., Field, R. A., Flynn, J. H., Gilman, J. B., Graus, M., Helmig, D., Koss, A., Langford, A. O., Lefer, B. L., Lerner, B. M., Li, R., Li, S.-M., McKeen, S. A., Murphy, S. M., Parrish, D. D., Senff, C. J., Soltis, J., Stutz, J., Sweeney, C., Thompson, C. R., Trainer, M. K., Tsai, C., Veres, P. R., Washenfelder, R. A., Warneke, C., Wild, R. J., Young, C. J., Yuan, B., and Zamora, R.: High winter ozone pollution from carbonyl photolysis in an oil and gas basin, Nature, 514, 351-354, 2014.

Heland, J., Kleffmann, J., Kurtenbach, R., and Wiesen, P.: A new instrument to measure gaseous nitrous acid (HONO) in the atmosphere, Environ. Sci. Technol., 35, 3207-3212, 2001.

Helmig, D., Thompson, C. R., Evans, J., Boylan, P., Hueber, J., and Park, J.-H.: Highly Elevated Atmospheric Levels of Volatile Organic Compounds in the Uintah Basin, Utah, Environ. Sci. Technol., 48, 4707-4715, 2014.

Huff, D. M., Joyce, P. L., Fochesatto, G. J., and Simpson, W. R.: Deposition of dinitrogen pentoxide, $\mathrm{N}_{2} \mathrm{O}_{5}$, to the snowpack at high latitudes, Atmos. Chem. Phys., 11, 4929-4938, doi:10.5194/acp11-4929-2011, 2011.

Kim, M. J., Farmer, D. K., and Bertram, T. H.: A controlling role for the air-sea interface in the chemical processing of reactive nitrogen in the coastal marine boundary layer, P. Natl. Acad. Sci., 111, 3943-3948, 2014.

Kleinman, L. I.: The dependence of tropospheric ozone production rate on ozone precursors, Atmos. Environ., 39, 575-586, 2005.

Koss, A. R., de Gouw, J., Warneke, C., Gilman, J. B., Lerner, B. M., Graus, M., Yuan, B., Edwards, P., Brown, S. S., Wild, R., Roberts, J. M., Bates, T. S., and Quinn, P. K.: Photochemical aging of volatile organic compounds associated with oil and natural gas extraction in the Uintah Basin, UT, during a wintertime ozone formation event, Atmos. Chem. Phys., 15, 5727-5741, doi:10.5194/acp-15-5727-2015, 2015.

Lee, L., Wooldridge, P. J., Gilman, J. B., Warneke, C., de Gouw, J., and Cohen, R. C.: Low temperatures enhance organic nitrate formation: evidence from observations in the 2012 Uintah Basin Winter Ozone Study, Atmos. Chem. Phys., 14, 12441-12454, doi:10.5194/acp-14-12441-2014, 2014.

McLaren, R., Singleton, D. L., Lai, J. Y. K., Khouw, B., Singer, E., $\mathrm{Wu}, \mathrm{Z}$., and Niki, H.: Analysis of motor vehicle sources and their contribution to ambient hydrocarbon distributions at urban sites in Toronto during the Southern Ontario Oxidants Study, Atmos. Environ., 30, 2219-2232, 1996.

McLaren, R., Wojtal, P., Majonis, D., McCourt, J., Halla, J. D., and Brook, J.: $\mathrm{NO}_{3}$ radical measurements in a polluted marine en- 
vironment: links to ozone formation, Atmos. Chem. Phys., 10, 4187-4206, doi:10.5194/acp-10-4187-2010, 2010.

Oltmans, S., Schnell, R., Johnson, B., Pétron, G., Mefford, T., and Neely III, R.: Anatomy of wintertime ozone associated with oil and natural gas extraction activity in Wyoming and Utah, Elem. Sci. Anth., 2, 000024, doi:10.12952/journal.elementa.000024, 2014.

Osthoff, H. D., Roberts, J. M., Ravishankara, A. R., Williams, E. J., Lerner, B. M., Sommariva, R., Bates, T. S., Coffman, D., Quinn, P. K., Dibb, J. E., Stark, H., Burkholder, J. B., Talukdar, R. K., Meagher, J., Fehsenfeld, F. C., and Brown, S. S.: High levels of nitryl chloride in the polluted subtropical marine boundary layer, Nat. Geosci., 1, 324-328, 2008.

Platt, U. and Stutz, J.: Differential Optical Absorption Spectroscopy, Principles and Applications, Springer, Heidelberg, 2008.

Rappenglück, B., Ackermann, L., Alvarez, S., Golovko, J., Buhr, M., Field, R. A., Soltis, J., Montague, D. C., Hauze, B., Adamson, S., Risch, D., Wilkerson, G., Bush, D., Stoeckenius, T., and Keslar, C.: Strong wintertime ozone events in the Upper Green River basin, Wyoming, Atmos. Chem. Phys., 14, 4909-4934, doi:10.5194/acp-14-4909-2014, 2014.

Roberts, J. M., Veres, P., Warneke, C., Neuman, J. A., Washenfelder, R. A., Brown, S. S., Baasandorj, M., Burkholder, J. B., Burling, I. R., Johnson, T. J., Yokelson, R. J., and de Gouw, J.: Measurement of HONO, HNCO, and other inorganic acids by negative-ion proton-transfer chemical-ionization mass spectrometry (NI-PT-CIMS): application to biomass burning emissions, Atmos. Meas. Tech., 3, 981-990, doi:10.5194/amt-3-981-2010, 2010.

Schnell, R. C., Oltmans, S. J., Neely, R. R., Endres, M. S., Molenar, J. V., and White, A. B.: Rapid photochemical production of ozone at high concentrations in a rural site during winter, Nat. Geosci., 2, 120-122, 2009.

Slusher, D. L., Huey, L. G., Tanner, D. J., Flocke, F. M., and Roberts, J. M.: A thermal dissociation-chemical ionization mass spectrometry (TD-CIMS) technique for the simultaneous measurement of peroxyacyl nitrates and dinitrogen pentoxide, J. Geophys. Res.-Atmos., 109, 2156-2202, 2004.
Veres, P. R., Roberts, J. M., Wild, R. J., Edwards, P. M., Brown, S. S., Bates, T. S., Quinn, P. K., Johnson, J. E., Zamora, R. J., and de Gouw, J.: Peroxynitric acid $\left(\mathrm{HO}_{2} \mathrm{NO}_{2}\right)$ measurements during the UBWOS 2013 and 2014 studies using iodide ion chemical ionization mass spectrometry, Atmos. Chem. Phys., 15, 81018114, doi:10.5194/acp-15-8101-2015, 2015.

Wagner, N. L., Dubé, W. P., Washenfelder, R. A., Young, C. J., Pollack, I. B., Ryerson, T. B., and Brown, S. S.: Diode laser-based cavity ring-down instrument for $\mathrm{NO}_{3}, \mathrm{~N}_{2} \mathrm{O}_{5}, \mathrm{NO}$, $\mathrm{NO}_{2}$ and $\mathrm{O}_{3}$ from aircraft, Atmos. Meas. Tech., 4, 1227-1240, doi:10.5194/amt-4-1227-2011, 2011.

Wagner, N. L., Riedel, T. P., Young, C. J., Bahreini, R., Brock, C. A., Dubé, W. P., Kim, S., Middlebrook, A. M., Öztürk, F., Roberts, J. M., Russo, R., Sive, B., Swarthout, R., Thornton, J. A., VandenBoer, T. C., Zhou, Y., and Brown, S. S.: $\mathrm{N}_{2} \mathrm{O}_{5}$ uptake coefficients and nocturnal $\mathrm{NO}_{2}$ removal rates determined from ambient wintertime measurements, J. Geophys. Res.-Atmos., 118, 9331-9350, 2013.

Wild, R. J., Edwards, P. M., Dubé, W. P., Baumann, K., Edgerton, E. S., Quinn, P. K., Roberts, J. M., Rollins, A. W., Veres, P. R., Warneke, C., Williams, E. J., Yuan, B., and Brown, S. S.: A Measurement of Total Reactive Nitrogen, $\mathrm{NO}_{\mathrm{y}}$, together with $\mathrm{NO}_{2}$, $\mathrm{NO}$, and $\mathrm{O}_{3}$ via Cavity Ring-down Spectroscopy, Environ. Sci. Technol., 48, 9609-9615, 2014.

Williams, E. J., Baumann, K., Roberts, J. M., Bertman, S. B., Norton, R. B., Fehsenfeld, F. C., Springston, S. R., Nunnermacker, L. J., Newman, L., Olszyna, K., Meagher, J., Hartsell, B., Edgerton, E., Pearson, J. R., and Rodgers, M. O.: Intercomparison of ground-based $\mathrm{NO}_{y}$ measurement techniques, J. Geophys. Res.Atmos., 103, 22261-22280, 1998.

Young, C. J., Washenfelder, R. A., Roberts, J. M., Mielke, L. H., Osthoff, H. D., Tsai, C., Pikelnaya, O., Stutz, J., Veres, P. R., Cochran, A. K., VandenBoer, T. C., Flynn, J., Grossberg, N., Haman, C. L., Lefer, B., Stark, H., Graus, M., de Gouw, J., Gilman, J. B., Kuster, W. C., and Brown, S. S.: Vertically resolved measurements of nighttime radical reservoirs in Los Angeles and their contribution to the urban radical budget, Environ. Sci. Technol., 46, 10965-10973, 2012. 